\title{
CUPPING THERAPY: A PRUDENT APPROACH IN PAIN MANAGEMENT-A SYSTEMATIC REVIEW
}

\begin{abstract}
\section{BACKGROUND AND AIMS}

Cupping Therapy is an ancient form of alternative medicine for treating variety of musculoskeletal disorders. Number of studies indicated the efficacy of various cupping methods in decreasing neck or back pain intensity within short duration and improves quality of life.
\end{abstract}

\section{DATABASES AND ELIGIBILITY CRITERIA}

The experimental studies were searched on the electronic databases including Google Scholar, PEDro, PubMed and Cochrane Library from June 2015 to December 2019. It was ensured that all articles were full-text in English language whereas screening was executed on relevant titles and abstracts, evaluated on the basis of cupping therapy and its effects on musculoskeletal pain.

\section{RESULTS}

A total of eight out of ten experimental studies showed significant decrease $(p<0.05)$ in spinal pain in result of cupping therapy except for the two studies that demonstrated no significant pre-post group differences $(p>0.05)$.

\section{CONCLUSION}

It was concluded that cupping therapy is effective in the management of pain due to various musculoskeletal ailments. Despite, high heterogeneity and low quality evidence limit the study findings therefore, the techniques required validation for the future implication for better understanding of the treatment outcomes.

\section{KEYWORDS}

Low back pain, Neck pain, Prevention, Rehabilitation, Spine, Disease, Therapeutic.
Hafiza Javeria

Lecturer

Ziauddin College Of Rehabilitation

Sciences

Ziauddin University

Javeria.mirza@zu.edu.pk

Yusra Obaid

Physiotherapist

Department of Physiotherapy

Park Lane Hospital.

yusraobaid@outlook.com

\section{Ismail Naseem}

Physiotherapist \& Coordinator Sultan Madadd health care (pvt Itd) ismail.naseem91@gmail.com

[Mirza HJ, Obaid Y, N Ismail. Cupping Therapy: A Prudent Approach In Pain Management-A Systematic Review. Pak. j. rehabil. 2021;10(1):6-]

10.36283/pjr.zu.10.1/003 


\section{INTRODUCTION}

Cupping Therapy, commonly known as Hijama or Vacuum therapy is a pre-historic part of Chinese alternative treatment and practices for the management of a variety of musculoskeletal, neuromuscular, and visceral disorders ${ }^{1}$. Moreover, the roots of cupping therapy may originate from Oriental, Tibetan or Unani medicine, however; its particular origin remains unclear ${ }^{1,2}$. Cupping therapy officially came in the 1950s among hospitals in China considering it to be a pseudoscience $^{3}$. The therapy is applied by the therapists using special cups onto some points over the skin to create suction that may help to reduce skin surface temperature, inflammation, and pain that may increase deep-tissue blood flow induces relaxation, and promotes healing ${ }^{3}$.

Cupping therapy has many types consisted of mainly four, in particular, wet, dry, massage, and flash cupping ${ }^{4}$. The term cupping is commonly known as Hijama, described by detoxification process by removing waste matter from the blood to bring vital energy within the body ${ }^{4,5}$. The dry cupping method involves a plastic or silicone cup that is placed on the skin and suctioned the drawn blood. However, in the wet cupping method, blood is drained from lacerated skin into the cup although; wet cupping is not applicable for people of all ages ${ }^{6}$. In addition to this, a variety of methods have been most commonly used in Asian and Middle Eastern Countries such as quick cupping, withholding, cupping with fire, moving or shaking etc $^{7}$. The evidence stated that momentarily attaching rounded and inverted cups to definite parts of the body using a vacuum effect results in drawing of the skin inside the cups that increases blood flow and flexibility to the area ${ }^{8}$. This mechanism increases the lactate-pyruvate ratio after 160 minutes thereby leads to anaerobic metabolism in the surrounding tissue with instantly increased pressure pain thresholds 9 . Moreover, it leads to the detoxification of the blood and extracts it from the body that is beneficial to treat a variety of problems and enhance the immune system ${ }^{9}$. Therefore, cupping therapy has been widely used due to its beneficence as it is an inexpensive, non-invasive and lowrisk modality compared to the other pharmacological treatments ${ }^{9}$.

Musculoskeletal disorders such as low back or neck pain have been increasing rapidly, affecting every third person worldwide affecting the quality of life ${ }^{10}$. According to World Health Organization (WHO), 70\% to $80 \%$ of people suffers from spinal pain, most commonly with neck and low back pain in young and old aged people due to a variety of factors including varying workload, bad posture, incorrect ergonomics of the furniture, degenerative changes and trauma that may lead an individual to compromised quality of life, social activities, emotional changes, and other problems ${ }^{11}$. People in chronic pain; tend to find different therapies to reduce pain and discomposure, even if those therapies have no enough scientific evidence ${ }^{12}$. Moreover, patients usually apply home remedies to reduce their pain and discomfort $^{12}$. Despite the facts, several studies have shown the positive impact of cupping therapy on the neck, back or shoulder region in decreasing pain intensity within a short duration and improve the quality of life $\mathrm{e}^{13}$. In addition to this, cupping therapy is further classified into light, medium, and strong cupping ${ }^{6}$. The therapist used light cupping for children in which pressure is very light or low ${ }^{6}$. In medium cupping, the pressure is medium or bearable for patients, commonly applied on adults whereas strong cupping is relatively solid, uncomfortable, and uncommonly used ${ }^{6}$. Furthermore, it has also evident that cupping therapy reduces muscle tenderness and swelling thereby decrease muscle pain, stimulates sleep, and promotes relaxation ${ }^{14}$.

However, the evidence-based rationale for use of cupping therapy is yet to be understood therefore, the present review is aimed to assess current trends of cupping therapy in musculoskeletal pain through the review of experimental studies for better 
understanding its effects on neck or back pain.

\section{METHODOLOGY}

The systematic review has followed Preferred Reporting Items for Systematic Reviews and Meta-Analyses (PRISMA) guidelines.

\section{DATA SOURCES AND SEARCHING STRATEGIES}

The authors identified and searched studies on learning resource centers and electronic databases that included MEDLINE, PubMed, Google Scholar, and Physiotherapy Evidence Database (PEDro). The databases were searched from June 2015 to December 2019 by using keywords such as "Dry Cupping", "Wet Cupping", "Pulsatile Cupping", and "Musculoskeletal Pain." Titles or abstracts were thoroughly reviewed and were excluded if not relevant to specified terms.

\section{ELIGIBILITY CRITERIA OF STUDIES}

The experimental studies included "Randomized Controlled Trials" considering Three-Armed, Parallel, SingleBlinded, Mono-Center, and Open-Label designs and "Quasi-experimental" that were selected from the tenure of 2015 to 2019 respectively. It was ensured that all articles were full-text in the English language; however, studies with a language barrier were excluded.

\section{DATA EXTRACTION}

The screening was executed on relevant titles and/or abstracts were included in the systematic review. All studies were evaluated on the following basis i.e. subjects with musculoskeletal pain, in particular neck or back pain, discriminate between acute and chronic phases. Also, dry or wet cupping methods, type of cupping whereas patients underwent usual care, traditional treatment, physical therapy, medicine, acupuncture, or no intervention were included as control groups.

\section{RISK OF BIAS}

The quality appraisal of the eligible studies was assessed and the risk of bias was measured on six domains comprised of random sequence, allocation concealment, participants blinding, outcome assessment blinding, incomplete outcome data, and selective reporting respectively.

\section{RESULTS}

\section{SELECTION OF STUDIES}

A total number of 80 records were analyzed from learning resource centers and databases. The articles relevant to the context of the objective were identified for screening based on eligibility. Only 10 full-text experimental studies conducted from 2015 to 2019 were included as shown in Figure-1.

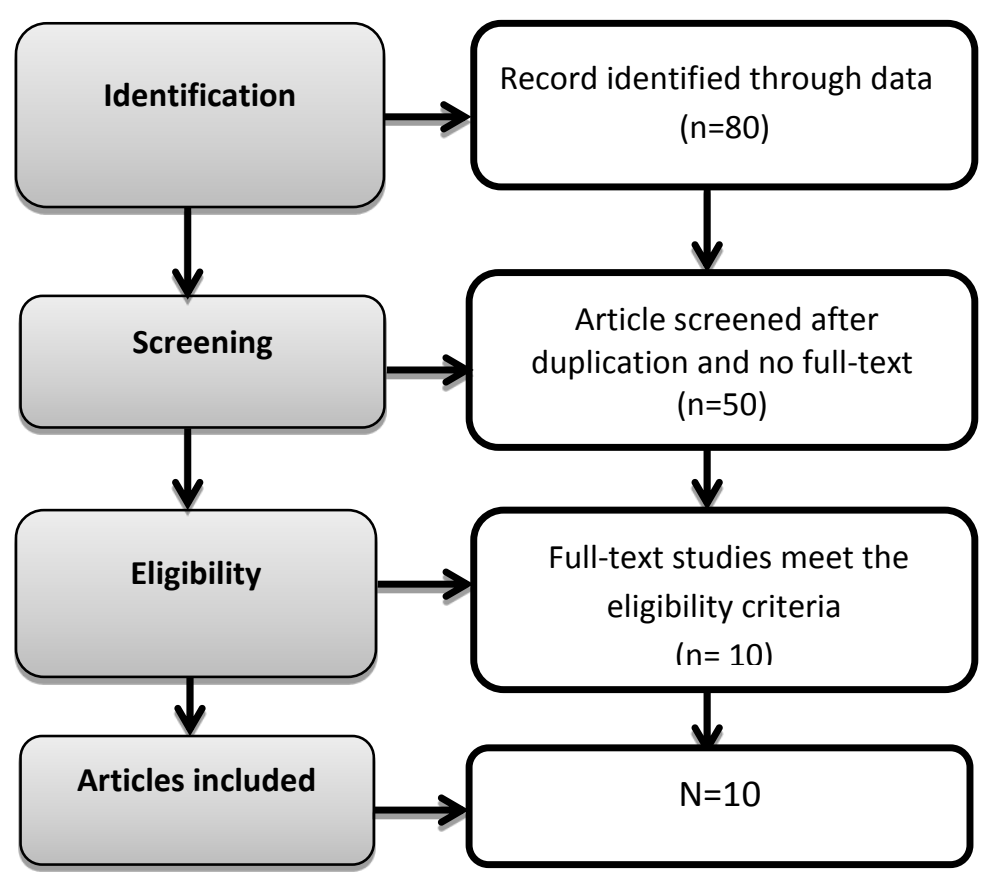

Figure-1 Flow diagram on identification and screening of eligible studies for inclusion 


\section{STUDY CHARACTERISTICS}

A total of 10 experimental studies were included in the study based on the number of designs in randomized controlled trials, however, only one study was quasi-experimental respectively. The type of cupping therapy was identified in each study considering sample size, target population, and intervention to determine the outcomes of the therapy.

\section{SYNTHESIS OF STUDIES}

A total of 10 studies were analyzed in a direct comparison of the cupping therapy or comparing with the cupping group with the control-only group. Although, the study of Gozubuyuk et $\mathrm{al}^{18}$ and Sadek et $\mathrm{al}^{22}$ conducted a trial on a relatively small sample size as compared to other studies $^{15,16,17,19,20,21,23,24}$ whereas Teut et $\mathrm{al}^{16}$ and Yazdanpanahi et al ${ }^{19}$ included a larger population. Several studies represented participants with chronic or non-specific low back pain for $\geq 3$ months due to varying occupations and factors such as childbirth or pregnancy. However, limited studies represented patients with non-specific neck pain persisted for $\geq 5$ weeks $^{23}$ or at least 3 months ${ }^{15,20}$. The region of administration was typically the upper shoulder and neck while cupping was primarily administered to acupoints such as SI 15, GB 21, and LI 1521 although only one study ${ }^{18}$ included healthy volunteers without any presence of pain. Studies have demonstrated a variety of cupping therapies i.e. dry, pulsatile, massages, at acupuncture points, dry moving respectively for a single session or several times in a week in alliance with medicine or acupuncture and control group with usual care or no intervention. Moreover, studies showed a significant decrease in spinal pain as a result of cupping therapy except for the Gozubuyuk et $\mathrm{al}^{18}$ and Sadek et $\mathrm{al}^{22}$ that demonstrated insignificant pre-post group differences. The description of the included studies is depicted in Table-1.

\section{RISK OF BIAS IN STUDIES}

The risk of bias was calculated through the Cochrane Risk of Bias Tool on the following domains is based on the author's perception as described in Table2:

\section{Random Sequence}

All the studies ${ }^{15,16,17,19,20,21,22,23,24}$ showed a low risk of bias except Gozubuyuk et al ${ }^{18}$ that indicated unknown bias.

\section{Allocation Concealment}

A low risk of bias was demonstrated in all studies.

\section{Participants Blinding}

Among ten studies, four ${ }^{16,19,22,23,24}$ cannot ensure bias; three ${ }^{17,18,20}$ indicates a high risk of bias whereas only two showed low bias $^{15,21}$.

\section{Outcome Assessment Blinding}

Out of 10 studies, six studies $15,16,17,18,19,20$ revealed high bias whereas four, ${ }^{21,22,23,24}$ showed unknown risk.

\section{Incomplete Outcome Data}

Five studies showed low $^{16,19,20,21,23,24}$ and high $^{15,17,18,20,22}$ risk respectively.

\section{Selective Reporting}

A low risk of bias is assumed in all studies. 
Table-1 Characteristics of included studies $(n=10)$

\begin{tabular}{|c|c|c|c|c|c|c|}
\hline $\begin{array}{l}\text { AUTHOR } \\
\text { (YEAR) }\end{array}$ & $\begin{array}{l}\text { SAMPLE } \\
\text { SIZE }\end{array}$ & $\begin{array}{l}\text { STUDY } \\
\text { DESIGN }\end{array}$ & $\begin{array}{c}\text { TARGET } \\
\text { POPULATION } \\
\text { Age (Mean } \pm S . D)\end{array}$ & INTERVENTION & RESULTS & P-VALUE \\
\hline $\begin{array}{l}\text { Stephens et } \mathrm{al}^{15} \text {. } \\
\text { (2019) }\end{array}$ & 30 & $\begin{array}{l}\text { Single-Blinded } \\
\text { Randomized } \\
\text { Controlled } \\
\text { Laboratory } \\
\text { Study }\end{array}$ & $\begin{array}{l}\text { Patients with } \\
\text { self-reported } \\
\text { non-specific } \\
\text { neck pain } \\
(22 \pm 2.6)\end{array}$ & $\begin{array}{l}\text { Single session of dry and } \\
\text { sham cupping intervention } \\
\text { for } 8 \text { minutes while control } \\
\text { group received no } \\
\text { intervention }\end{array}$ & $\begin{array}{c}\text { Decrease in } \\
\text { subjective pain } \\
\text { intensity while } \\
\text { hemoglobin levels } \\
\text { significantly } \\
\text { increased within the } \\
\text { dry cupping group }\end{array}$ & .049 \\
\hline $\begin{array}{l}\text { Teut et } \mathrm{al}^{16} \text {. } \\
\text { (2018) }\end{array}$ & 110 & $\begin{array}{l}\text { Three-Armed, } \\
\text { Parallel, } \\
\text { Participant } \\
\text { Blinded Mono- } \\
\text { Center } \\
\text { Randomized } \\
\text { Controlled } \\
\text { Clinical Trial }\end{array}$ & $\begin{array}{c}\text { Patients with the } \\
\text { clinical diagnosis } \\
\text { of non-specific } \\
\text { chronic low back } \\
\text { pain of at least } 3 \\
\text { months } \\
(49 \pm 13.7)\end{array}$ & $\begin{array}{l}\text { Regular pulsatile cupping } \\
\text { with } 8 \text { treatments plus } \\
\text { paracetamol or the control } \\
\text { group with paracetamol } \\
\text { only }\end{array}$ & $\begin{array}{l}\text { Pulsatile cupping } \\
\text { showed significant } \\
\text { effects compared to } \\
\text { control after } 12 \\
\text { weeks }\end{array}$ & $<0.05$ \\
\hline $\begin{array}{l}\text { Sharma et } a^{17} \text {. } \\
(2018)\end{array}$ & 60 & $\begin{array}{l}\text { Randomized } \\
\text { Controlled } \\
\text { Trial }\end{array}$ & $\begin{array}{c}\text { Female students } \\
\text { with chronic low } \\
\text { back pain for } 3 \\
\text { months } \\
(19 \pm 1.5)\end{array}$ & $\begin{array}{l}\text { Tens and Cupping therapy } \\
\text { was given for the duration } \\
\text { of } 5 \text { mins and } 10 \text { mins } \\
\text { respectively }\end{array}$ & $\begin{array}{l}\text { Cupping therapy is } \\
\text { equally effective as } \\
\text { compared to Tens in } \\
\text { decreasing pain }\end{array}$ & $<0.05$ \\
\hline $\begin{array}{l}\text { Gozubuyuk et } \\
\mathrm{al}^{18} \cdot(2018)\end{array}$ & 20 & $\begin{array}{l}\text { Quasi- } \\
\text { Experimental } \\
\text { Study }\end{array}$ & $\begin{array}{c}\text { Healthy } \\
\text { volunteers } \\
\text { (Not Specified) }\end{array}$ & $\begin{array}{l}\text { The cupping was applied } \\
\text { to one side (suctioned) } \\
\text { and the other side served } \\
\text { as a control } \\
\text { (non-suction) }\end{array}$ & $\begin{array}{l}\text { Groups were not } \\
\text { different significantly } \\
\text { in terms of thickness } \\
\text { and stiffness }\end{array}$ & $>0.05$ \\
\hline $\begin{array}{l}\text { Yazdanpanahi et } \\
\mathrm{al}^{19} \text {. } \\
(2017)\end{array}$ & 100 & $\begin{array}{l}\text { Randomized } \\
\text { Clinical Trial }\end{array}$ & $\begin{array}{l}\text { Mother suffering } \\
\text { from low back } \\
\text { pain due to } \\
\text { lordosis resulting } \\
\text { from pregnancy } \\
\text { and childbirth } \\
(25 \pm 4.2)\end{array}$ & $\begin{array}{l}\text { Cupping therapy for } 15-20 \\
\text { mins sessions a week, } \\
\text { while acupressure was } \\
\text { applied for } 20 \text { minutes }\end{array}$ & $\begin{array}{l}\text { Significant variance } \\
\text { in pain was found } \\
\text { between the three } \\
\text { follow-up periods }\end{array}$ & $<0.05$ \\
\hline
\end{tabular}




\begin{tabular}{|c|c|c|c|c|c|c|}
\hline $\begin{array}{l}\text { Saha et } \mathrm{al}^{20} \text {. } \\
\text { (2017) }\end{array}$ & 45 & $\begin{array}{l}\text { Randomized } \\
\text { Controlled } \\
\text { Clinical Trial }\end{array}$ & $\begin{array}{c}\text { Participants with } \\
\text { non-specific neck } \\
\text { pain for at least } \\
3 \text { months } \\
(52.6 \pm 10.3)\end{array}$ & $\begin{array}{l}\text { The intervention } \\
\text { group received } 5 \\
\text { cupping massages } \\
\text { twice-weekly basis } \\
\text { while the control } \\
\text { patients continued } \\
\text { their usual } \\
\text { treatment }\end{array}$ & $\begin{array}{l}\text { Cupping group } \\
\text { reported significantly } \\
\text { less neck pain post } \\
\text { intervention }\end{array}$ & .047 \\
\hline $\begin{array}{l}\text { Chi et } \mathrm{al}^{21} \text {. } \\
(2016)\end{array}$ & 60 & $\begin{array}{l}\text { Single-Blind } \\
\text { Experimental } \\
\text { Design }\end{array}$ & $\begin{array}{c}\text { Subjects with } \\
\text { diagnosed and self- } \\
\text { perceived chronic } \\
\text { non-specific pain } \\
(43.6 \pm 8)\end{array}$ & $\begin{array}{l}\text { The cupping group } \\
\text { received therapy at } \\
\text { SI } 15, \text { GB } 21 \text {, and LI } \\
15 \text { acupuncture } \\
\text { points whereas } \\
\text { control group } \\
\text { received no } \\
\text { intervention }\end{array}$ & $\begin{array}{c}\text { Skin surface } \\
\text { temperature and } \\
\text { neck pain differences } \\
\text { between the groups } \\
\text { were statistically } \\
\text { significant }\end{array}$ & $<0.001$ \\
\hline $\begin{array}{l}\text { Sadek et } \mathrm{al}^{22} \text {. } \\
(2016)\end{array}$ & 20 & $\begin{array}{l}\text { Randomized } \\
\text { Control Trial }\end{array}$ & $\begin{array}{l}\text { Athletes with low } \\
\text { back pain for } \geq 3 \\
\text { months } \\
(23.45 \pm 2.4)\end{array}$ & $\begin{array}{l}\text { Cupping therapy } \\
\text { was performed for } \\
\text { two days in a week } \\
\text { for one-week for } \\
\text { experimental group } \\
\text { while control group } \\
\text { received no } \\
\text { intervention }\end{array}$ & $\begin{array}{l}\text { The experimental } \\
\text { group showed } \\
\text { improvement } \\
\text { increase in lumbar } \\
\text { spine flexion and } \\
\text { extension but } \\
\text { insignificant pre-post } \\
\text { results }\end{array}$ & 0.651 \\
\hline $\begin{array}{l}\text { Arslan et }\left.a\right|^{23} \text {. } \\
(2015)\end{array}$ & 40 & $\begin{array}{c}\text { Randomized } \\
\text { Parallel-Group } \\
\text { Trial }\end{array}$ & $\begin{array}{l}\text { Office workers } \\
\text { with neck pain for } \\
\quad \geq 5 \text { weeks } \\
(44.6 \pm 1.9)\end{array}$ & $\begin{array}{l}10 \text { dry moving } \\
\text { cupping therapy } \\
\text { sessions over a } 5 \\
\text { week period }\end{array}$ & $\begin{array}{c}\text { Statistically } \\
\text { significant reduction } \\
\text { in pain in } \\
\text { intervention group }\end{array}$ & 0.002 \\
\hline $\begin{array}{l}\text { AlBedah et } \mathrm{al}^{24} \text {. } \\
\text { (2015) }\end{array}$ & 80 & $\begin{array}{l}\text { Randomized, } \\
\text { Controlled, } \\
\text { Open-Label, } \\
\text { Parallel Trial }\end{array}$ & $\begin{array}{l}\text { Patients with non- } \\
\text { specific low back } \\
\text { pain for at least } 3 \\
\text { months } \\
(36.48 \pm 9.3)\end{array}$ & $\begin{array}{c}\text { Six wet cupping } \\
\text { sessions within } 2 \\
\text { weeks done at two } \\
\text { acupuncture points } \\
\text { whereas only } \\
\text { acetaminophen was } \\
\text { allowed as a rescue } \\
\text { treatment in both } \\
\text { groups }\end{array}$ & $\begin{array}{l}\text { Statistically } \\
\text { significant } \\
\text { differences in pain } \\
\text { favoring the wet } \\
\text { cupping group } \\
\text { compared with the } \\
\text { control group }\end{array}$ & 0.0001 \\
\hline
\end{tabular}




\section{Table-2 Cochrane Summary for Risk of Bias $(n=10)$}

\begin{tabular}{|c|c|c|c|c|c|c|}
\hline Studies & 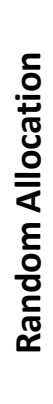 & 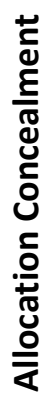 & 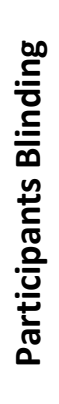 & 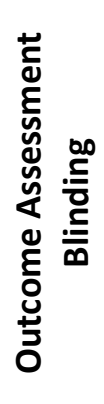 & 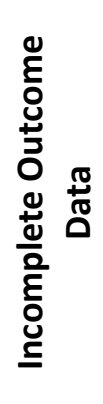 & 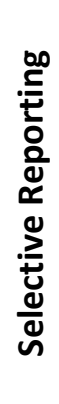 \\
\hline $\begin{array}{l}\text { Stephens et al }{ }^{15} \text {. } \\
\text { (2019) }\end{array}$ & + & + & + & - & - & + \\
\hline $\begin{array}{l}\text { Teut et al }{ }^{16} \text {. } \\
\text { (2018) }\end{array}$ & + & + & ? & - & + & + \\
\hline $\begin{array}{l}\text { Sharma et } \mathrm{al}^{17} \text {. } \\
\text { (2018) }\end{array}$ & + & + & - & - & - & + \\
\hline $\begin{array}{l}\text { Gozubuyuk et al }{ }^{18} \text {. } \\
\text { (2018) }\end{array}$ & ? & + & - & - & - & + \\
\hline $\begin{array}{l}\text { Yazdanpanahi et al }{ }^{19} \\
\text { (2017) }\end{array}$ & + & + & ? & - & + & + \\
\hline $\begin{array}{l}\text { Saha et } \mathrm{al}^{20} . \\
\text { (2017) }\end{array}$ & + & + & - & - & + & + \\
\hline $\begin{array}{l}\text { Chi et al }{ }^{21} \text {. } \\
(2016)\end{array}$ & + & + & + & ? & + & + \\
\hline $\begin{array}{l}\text { Sadek et al }{ }^{22} \text {. } \\
(2016)\end{array}$ & + & + & $?$ & $?$ & - & + \\
\hline $\begin{array}{l}\text { Arslan et } \mathrm{al}^{23} \text {. } \\
\text { (2015) }\end{array}$ & + & + & ? & $?$ & + & + \\
\hline $\begin{array}{l}\text { AlBedah et } \mathrm{al}^{24} \text {. } \\
\text { (2015) }\end{array}$ & + & + & $?$ & ? & + & + \\
\hline \multicolumn{7}{|c|}{$\begin{array}{l}- \text {, indicates high risk of bias } \\
+, \text { indicates low risk of bias } \\
?, \text { indicates that cannot ensure risk of bias. }\end{array}$} \\
\hline
\end{tabular}




\section{DISCUSSION}

The results of this analysis demonstrated current trends of cupping therapy in the management of musculoskeletal pain, in the particular neck and low back pain. The analysis of ten randomized controlled trials evaluated in this study has shown positive results in decreasing neck and low back pain, in particular physiological parameters of pain in adults that contributed to the consolidation of the use of cupping treatment in the clinical condition of the targeted population thereby improving quality of life.

A review conducted by Aboushanab et $\mathrm{al}^{1}$ demonstrated cupping therapy as old and reliable therapy in patients with neck and back pain in which it reduces inflammation, enhances blood flow, and leads to deep-tissue massage by creating a suction. Likewise, studies conducted by Stephen et $\mathrm{al}^{15}$, Saha et $\mathrm{al}^{20}$, and Arsalan et $\mathrm{al}^{23}$ demonstrated a significant decrease in neck pain intensity postintervention whereas another studies $^{16,17,18,19,21,22,24}$ was found to be significantly reducing low back pain after cupping sessions. Besides, another review indicated a positive effect of the mechanism of cupping therapy regime ${ }^{25}$. Furthermore, the hemodynamic mechanism facilitating muscle function was observed with elevated oxygen levels in surrounding tissues during cupping sessions ${ }^{25}$. Similarly, the study of Stephen et $\mathrm{al}^{15}$ also revealed increased hemoglobin levels that were significantly increased within the dry cupping group. Despite this, it was also observed that however the most applied technique among all types is dry cupping, applied particularly on the cervical and lumbar regions, often used with the stimulation of the acupoints primarily on the urinary bladder, gallbladder, and small intestine. The stimulation also prevailed over the bladder meridian, similarly followed by trigger points as acupuncture techniques yet no standardization is available concerning the application of acupoints over the body for cupping therapy ${ }^{25-26}$. Several studies also suggested that wet cupping promotes nociceptive stimulus that leads to the activation of the descending pathways of pain regulation. Hence the technique is found to be beneficial for certain musculoskeletal disorders ${ }^{1,23}$. On the other hand, infection risk, scar formation, and a vasovagal attack may occur as the disadvantage of cupping $^{24}$. Despite the facts, many authors have emphasized the greater analgesic effect of dry cupping as compared to any other techniques, as the usage of lubrication may decrease the friction between the cup edge and the skin. This mechanism is often termed cupping massage ${ }^{1-4}$. Despite the effectiveness of these, methods, no standardization is established for the management of spinal pain ${ }^{26}$. Therefore, it has been concluded that appropriate technique, number of sessions, suction points, strength, and duration of the session have not been determined specifically in the studies. Further, limited variables were identified about the nature of the study and target population. However, variable suction strength was observed to be used in the studies whereas according to standardized protocols, light suction of 100 to 300 millibar with two manual pumpings, medium suctions of 500 millibars with five or more pumping or pulsatile pressure between 100 to 200 millibar every 2 seconds ${ }^{20-25}$. Among these, medium, suction is indicated to be painful for musculoskeletal conditions. However, these methods did not sufficiently describe in the studies, despite considerable variation in the application of cupping type, specifically to the difference with the control group has been shown in several studies. Despite the varying application of cupping therapy, the average session was 
impossible to identify although, in one study, cupping session was applied for 5 sessions around 8 minutes for the interval of 3-4 days ${ }^{27}$. Moreover, some researchers concluded that at least 5 sessions are required to observe any significant changes of intervention to ensuring the feasibility of the study ${ }^{27,28}$. Moreover, it has also been suggested that interval periods between cupping sessions are crucial for the re-establishment of tissues $^{29}$. The analysis further revealed that most of the studies showed a low quality of evidence. Furthermore, high heterogeneity was found between the studies, moreover, a significant decrease in pain was found in association with cupping therapy. However, these outcomes may be clinically relevant in experimental in comparison to control groups.

Moreover, only one variable was demonstrated in the extraction of data. Therefore, additional analysis is required for the clarity of the difference between the study groups attributed to different cupping techniques. Although, the effectiveness of these techniques are still needed to be confirmed based on subgroup analysis constitutes of different application techniques in intervention and control groups. Thus, meta-analysis should be performing to determine the heterogeneity of trials.

In recent decades, several clinical trials have been conducted to determine the role of cupping intervention on various neurological and infectious diseases ${ }^{30}$. A comprehensive systematic review was conducted to investigate cupping therapy is associated with diseases ${ }^{31}$ however it included articles about musculoskeletal conditions only. Moreover, this review has several limitations as none of the studies reported safety issues and side effects from the treatment. Further studies are required to apprehend whether different kind of cupping is effective for musculoskeletal disorders or in overall diseases as an alternative medicine although, its wider acceptance and practice in holistic health care departments is crucial. Moreover, these protocols are needed to be validated for future trials to evaluate the health-related outcomes in clinical conditions to determine the behavioral and physiological parameters.

\section{CONCLUSION}

It was concluded that cupping therapy is effective in the management of pain due to various musculoskeletal ailments. The qualitative analysis showed a significant decrease in pain intensity among participants, besides there is variation in applying various cupping methods and regimes. Despite, high heterogeneity and low-quality evidence limit the study findings therefore, the techniques required validation for the future implication.

\section{REFERENCES}

[1] Aboushanab TS, AlSanad S. Cupping therapy: an overview from a modern medicine perspective. J

Acupunct Meridian Stud. 2018 Jun 1;11(3):83-7.

[2] Cooper R, Che CT, Mok DK, Tsang CW. Chinese and Botanical Medicines: Traditional Uses and Modern Scientific Approaches. CRC Press; 2017 Sep 6.

[3] Dalton EL, Velasquez BJ. Cupping therapy: An alternative method of treating pain. Public Health Open J. 2017;2(2):59-63.

[4] Qureshi NA, Al-Bedah AM, Abushanab TS. Cupping Hijama Therapy Skin Marks: What Should We Know About Them?. Int. J. Dermatol. 2017;43(9):664-5.

[5] Qureshi NA, Ali GI, Abushanab TS, ElOlemy AT, Alqaed MS, El-Subai IS, AlBedah AM. History of cupping (Hijama): a narrative review of literature. J Integr Med. 2017 May 31;15(3):172-81. 
[6] Al-Bedah AM, Aboushanab TS, Alqaed MS, Qureshi NA, Suhaibani I, Ibrahim G, Khalil $M$. Classification of cupping therapy: a tool for modernization and standardization.

$\mathrm{J}$

Altern Complement Med. 2016 Jun 23:10.

[7] Gold R. Seitai (Lymphatic) Shiatsu, Cupping and Gua Sha for a Healthy Immune System. Singing Dragon; 2019 May 21.

[8] Stoner S, Petrizzo J, Wygand JW, Otto RM. The Effects of Acute Cupping Therapy on Balance, Flexibility and Muscular Power: 3728 Board\# 175 June 3930 AM-1100 AM. Med. Sci. Sports Exerc. 2017 May 1;49(5S):1070.

[9] Azizkhani M, Ghorat F, Soroushzadeh SM, Karimi M, Yekaninejad S. The effect of cupping therapy on non-specific neck pain: A systematic review and metaanalysis. Iran. Red. Crescent. Med. J. 2018 Jul;20(7).

[10] Jones C, Stephens J, Gatchel RJ. Musculoskeletal Pain and Disability Disorders. InHandbook of Rehabilitation in Older Adults 2018 (pp. 125-143). Springer, Cham.

[11] Brennan-Olsen SL, Cook S, Leech MT, Bowe SJ, Kowal P, Naidoo N, Ackerman IN, Page RS, Hosking SM, Pasco JA, Mohebbi $M$. Prevalence of arthritis according to age, sex and socioeconomic status in six low and middle income countries: analysis of data from the World Health Organization study on global AGEing and adult health (SAGE) Wave 1. BMC musculoskeletal disorders. 2017 Dec 1;18(1):271.

[12] Sherman A, Chin J. Cannabis and CBD for Health and Wellness: An Essential Guide for Using Nature's Medicine to Relieve Stress, Anxiety, Chronic Pain, Inflammation, and More. Ten Speed Press; 2019 Jun 4.

[13] Moura CD, Chaves ÉD, Cardoso AC, Nogueira DA, Corrêa HP, Chianca TC. Cupping therapy and chronic back pain: systematic review and meta-analysis.
Revista latino-americana de enfermagem. 2018;26.

[14] Wang H, Hu Y. Traditional Chinese Medicine Cupping and Health. InInternational Conference on Health and Well-Being in Modern Society (ICHW 2019) 2019 Oct. Atlantis Press.

[15]Stephens, Stephanie Lynn. The Immediate Effects of Dry Cupping Therapy on Subcutaneous Hemodynamics and Pain Associated With Nonspecific Neck Pain, 2019.

[16]Teut $M$, Ullmann $A$, Ortiz $M$, Rotter $G$, Binting $S$, Cree $M$, Lotz $F$, Roll S, Brinkhaus B. Pulsatile dry cupping in chronic low back pain-a randomized three-armed controlled clinical trial. BMC Complemen Altern Med. 2018 Dec 1;18(1):115.

[17]Sharma M, Asif M, Rai RH, Akhtar Z, Hussain MS. Therapies over Medication: Comparing the Effect of Tens and Cupping Therapy to Enhance the Performance in Female College Going Students. EJPESS. 2018 Oct 21.

[18]Gozubuyuk OB, Devran S, Akikol M. The effects of dry cupping therapy on muscle thickness and elasticity of upper back muscles. J Bodyw Mov Ther. 2018 Oct 1;22(4):851.

[19]Yazdanpanahi Z, Ghaemmaghami $M$, Akbarzadeh $M$, Zare N, Azisi A Comparison of the effects of dry cupping and acupressure at acupuncture point (BL23) on the women with postpartum low back pain (PLBP) based on short form McGill pain questionnaires in Iran: a randomized controlled trial. JFRH. 2017 Jun;11(2):82.

[20]Saha FJ, Schumann S, Cramer H, Hohmann C, Choi KE, Rolke R, Langhorst J, Rampp T, Dobos $G$, Lauche R. The effects of cupping massage in patients with chronic neck pain-a randomised controlled trial. J. Complement. Med. Res. 2017;24(1):2632.

[21]Chi LM, Lin LM, Chen CL, Wang SF, Lai HL, Peng TC. The effectiveness of cupping therapy on relieving chronic neck and shoulder pain: a randomized controlled 
trial. Evid. Based Complementary Altern. Med. 2016;2016.

[22]Sadek TA. Effects of cupping therapy based on stabilization core exercises on low back pain for soccer players in state of United Arab Emirates. Ovidius University Annals, Series Physical Education \& Sport/Science, Movement \& Health. 2016 Jul 2;16.

[23]Arslan $M$, Yaman $G$, Ilhan E, Alemdag $M$, Bahar A, Dane S. Moving Dry Cupping Therapy Reduces Upper Shoulder and Neck Pain in Office Workers. Clin Invest Med. 2015. 38. 217-220.

[24] AlBedah A, Khalil M, Elolemy A, Hussein AA, AlQaed M, Al Mudaiheem A, Abutalib RA, Bazaid FM, Bafail AS, Essa A, Bakrain $M Y$. The use of wet cupping for persistent nonspecific low back pain: randomized controlled clinical trial. J Altern Complement Med. 2015 Aug 1;21(8):504-8.

[25] Li T, Li Y, Lin $Y$, et al. Significant and sustaining elevation of blood oxygen induced by Chinese cupping therapy as assessed by near infrared spectroscopy. Biomed Opt Express 2017;8:223-9

[26] Nielsen A, Kligler B, Koll BS. Safety protocols for gua sha (press-stroking) and baguan (cupping) Complement Ther Med. 2012;20(5):340-344.

[27] Lauche R, Cramer $H$, Choi KE, Rampp T, Saha FJ, Dobos GJ, et al. The influence of a series of five dry cupping treatments on pain and mechanical thresholds in patients with chronic non-specific neck pain-a randomised controlled pilot study. BMC Complement Altern Med. 2011;18(6):327-334.

[28] Tham LM, Lee HP, Lu C. Cupping: From a biomechanical perspective. J Biomech. 2006;39(12):2183-2193.

[29] Markowski A, Sanford S, Pikowski J, Fauvell D, Cimino D, Caplan S. A Pilot Study Analyzing the Effects of Chinese Cupping as an Adjunct Treatment for Patients with Subacute Low Back Pain on Relieving Pain, Improving Range of
Motion, and Improving Function. J Altern Complement Med. 2014;20(2):113-117.

[30] Cao H, Li X, Liu J. An updated review of the efficacy of cupping therapy. PLoS One 2012;7:e31793.

[31] Al Bedah AM, Khalil MK, Posadzki P, et al. Evaluation of wet cupping therapy: systematic review of randomized clinical trials. J Altern Complement Med 2016;22:768-77. 